\title{
Coal and hard rock resources in Bangladesh
}

\author{
Geological Survey of Bangladesh, 153 Pioneer Road, Segunbagicha, Dhaka 1000, Bangladesh
}

Previously it was assumed that the geological setting of Bangladesh was more suitable for hydrocarbon accumulation than any other minerals, as major parts of the country are covered by thick alluvium. Now, it has been proved by geological and geophysical exploration that Bangladesh has huge deposits of coal and hard rock in its $N W$ region. Total reserves of about 1,753 million tons of high-quality bituminous coal have been reported from three coal fields-Jamalganj, Barapukuria, and Khalaspir - and a huge reserve of hard rock from Maddhyapara. Proper development of these mineral resources will open a new era for Bangladesh to enter the industrial world. It is expected that extraction of about 70 million tons of coal will be possible from the Barapukuria coal field. From the Maddhyapara hard rock mine, about 1.65 million tons of hard rock can be mined each year. Full-fledged exploitation of these mineral resources will create thousands of new jobs at the mine site and later on in the industrial sectors. It will also help Bangladesh to save considerable amounts of foreign currencies, which will contribute a great deal to the national economy, and thus improve the socio-economic infrastructure of the country.

\section{Introduction}

Availability of natural resources and their proper application to overall development activities is the key factor for the economic growth of any nation. Bangladesh, though it is a small country of about $143,998 \mathrm{sq} \mathrm{km}$, has a number of mineral resources within its territory. The mineral resources so far discovered are mineral fuels (oil, gas, coal, peat), hard rock, limestone, white clay, glass sand and heavy mineral sands. It was previously assumed that the geological setting of Bangladesh was more suitable for hydrocarbon accumulation than for any other mineral deposits as the greater part of Bangladesh is covered by thick alluvium. Nowadays, the assumption has been changed as it is proved by detailed geological and geophysical explorations that Bangladesh is rich not only in hydrocarbon accumulation but that it also has huge deposits of coal and hard rock in its north-northwestern part.

\section{Coal and hard rock deposits}

Coal: High-quality bituminous type Gondwana coal of Permo-Carboniferous age has been discovered at five places-Barapukuria, Dighipara and Phulbari in Dinajpur district, Khalaspir in Rangpur district and Jamalganj in Bogra district. Besides these, coal is also recorded from Kuchma in Bogra and Maddhapara in Dinajpur dis- trict. All these coal fields are located in the north-northwestern part of the country.

The Jamalgonj coal field, discovered by the Geological Survey of Bangladesh (GSB) in 1962, is the largest deposit in the country, with probable and proved reserves of 1,460 and 1,053 million tons, respectively. The coal field covers an area of $11.66 \mathrm{~km}^{2}$. The number of coal beds is 7, the average thickness of which is $64 \mathrm{~m}$. But the coal seams lie at a considerable depth of 640-158 m, the extraction of which is not economically feasible.

The Barapukuria coal field in Dinajpur district and the Khalaspir coal field in Rangpur district were also discovered by the GSB in 1985 and 1987, respectively. The Barapukuria coal field covers an area of $5.25 \mathrm{~km}^{2}$. The coal is at a shallower depth of $116 \mathrm{~m}$ and coal beds extend to a depth of $506 \mathrm{~m}$. The number of coal seams is 6 , the average thickness of which is $51 \mathrm{~m}$. The probable reserve of coal is about 389 million tons. But reserves of 300 million tons have been proved by Armstrong (1991).

The Khalaspir coal field occupies an area of about $12.26 \mathrm{~km}^{2}$ and the coal bed occurs at a depth of $257 \mathrm{~m}$, and the coal layer extends to a depth of $483 \mathrm{~m}$. The number of coal beds is 8 and their average thickness is $42.30 \mathrm{~m}$. The probable and proved reserves are 685 and 143 million tons, respectively (Islam et al., 1997).

The coal fields of Dighipara and Phulbari, in Dinajpur district were discovered in 1995 and 1997 respectively by GSB and BHP, an Australian company working in Bangladesh. At Dighipara, coal is

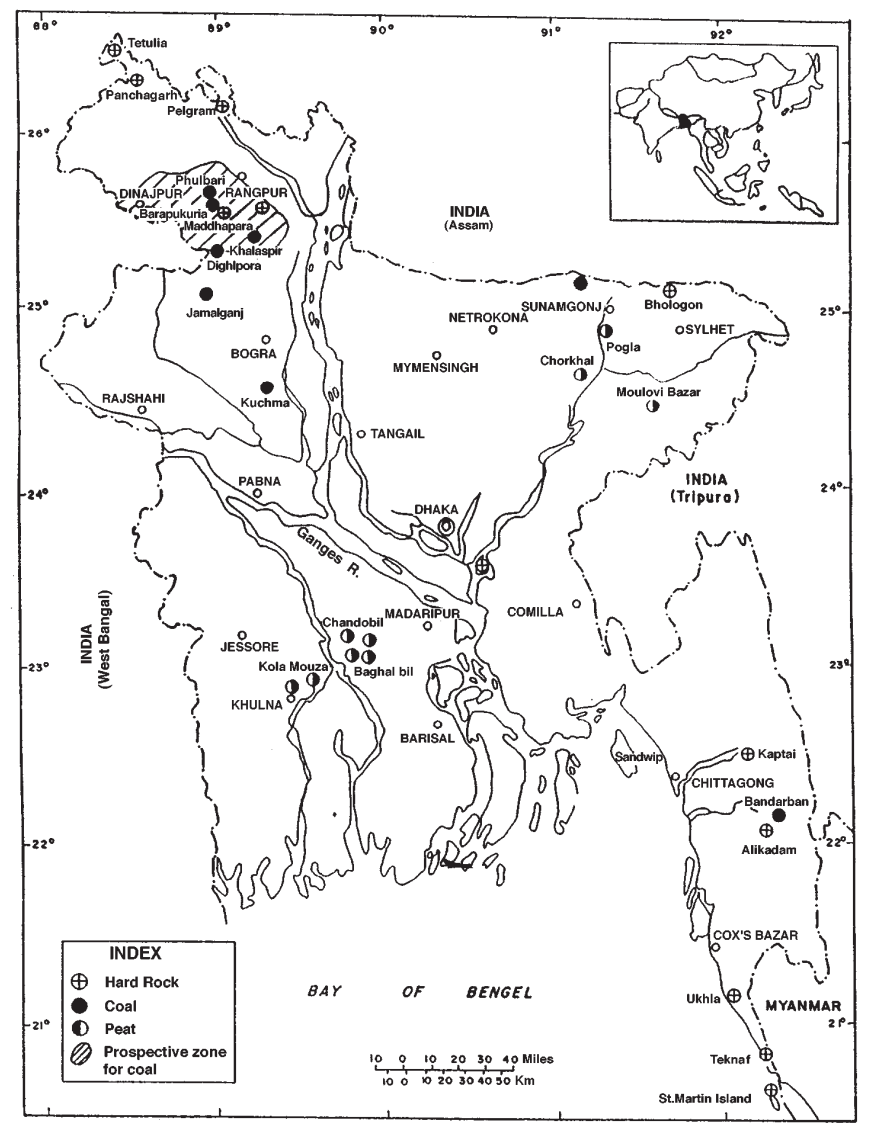

Figure 1 Coal and hard rock deposits in Bangladesh. 
Table 1 Details of coal fields of Bangladesh.

\begin{tabular}{|c|c|c|c|c|c|c|c|c|c|}
\hline Coal fields & $\begin{array}{l}\text { Years of } \\
\text { discovery }\end{array}$ & $\begin{array}{c}\text { Discovering } \\
\text { organizations }\end{array}$ & $\begin{array}{l}\text { Depth of } \\
\text { coal bed (m) }\end{array}$ & $\begin{array}{c}\text { Number of } \\
\text { coal beds }\end{array}$ & $\begin{array}{l}\text { Average thicknes } \\
\text { of coal bed (m) }\end{array}$ & Ss $\begin{array}{r}\text { Type } \\
\text { of coal }\end{array}$ & $\begin{array}{l}\text { Area of coal } \\
\text { fields }\left(\mathbf{k m}^{2}\right)\end{array}$ & $\begin{array}{l}\text { Reserves in } \\
\text { million tons }\end{array}$ & Remarks \\
\hline $\begin{array}{l}\text { Phulbari } \\
\text { (Dinajpur) }\end{array}$ & 1997 & BHP & 150 & & 38.41 & Bituminous & & $\begin{array}{c}\text { Not yet } \\
\text { Determined }\end{array}$ & \\
\hline $\begin{array}{l}\text { Dighipara } \\
\text { (Dinajpur) }\end{array}$ & 1995 & GSB & 328 & & 42.00 & Bituminous & & $\begin{array}{l}\text { Not yet } \\
\text { Determined }\end{array}$ & \\
\hline $\begin{array}{l}\text { Khalaspir } \\
\text { (Rangpur) }\end{array}$ & 1989 & GSB & $257-482$ & 8 & 42.30 & Bituminous & 12.26 & 400 & $\begin{array}{l}\text { Mining is under } \\
\text { consideration }\end{array}$ \\
\hline $\begin{array}{l}\text { Barapukuria } \\
\text { (Dinajpur) }\end{array}$ & a 1985 & GSB & $116-506$ & 6 & 51 & Bituminous & 5.25 & 300 & $\begin{array}{l}\text { Mining work is } \\
\text { going on }\end{array}$ \\
\hline $\begin{array}{l}\text { Jamalgonj } \\
\text { (Bogra) }\end{array}$ & 1962 & GSP & $640-1158$ & 7 & 64 & Bituminous & 11.66 & 1053 & $\begin{array}{c}\text { Extr.of Methane } \\
\text { Gas is under } \\
\text { consideration }\end{array}$ \\
\hline $\begin{array}{l}\text { Kuchma } \\
\text { (Bogra) }\end{array}$ & 1959 & SOVC & $2380-2876$ & 5 & 51.82 & Bituminous & $\begin{array}{l}\text { Not } \\
\text { recorded }\end{array}$ & $\begin{array}{l}\text { Not } \\
\text { recorded }\end{array}$ & \\
\hline
\end{tabular}

(Source: GSB, Petrobangla)

recorded at a depth of 328-422 $\mathrm{m}$ and the overall thickness of the coal layer is $42 \mathrm{~m}$. In the case of Phulbari, coal is recorded at a shallower depth of $150 \mathrm{~m}$ and the overall thickness of the coal layer is $38.41 \mathrm{~m}$ (Rahman, 1997). The extension of coal field areas and the reserves of coal have not yet been determined.

The Gondwana coal of bituminous type was first recorded in this country in the Kuchma area in Bogra district in the same region by SVOC in 1959 . The coal beds lie at a depth of 2381-2867 m. The number of coal beds is 5 and their average thickness is $51.82 \mathrm{~m}$ (Rahman, 1997). The area of the coal field and its reserves have not been determined, as coal extraction has not been considered economically feasible from such a great depth. Since then, work by geoscientists to find other prospective zones resulted in the above described economically viable coal fields. Some more prospective areas for coal have been pointed out in the same region, i.e. in the northwestern part of the country, which need to be explored. The locations and details of the present coal field of Bangladesh are shown in Figure 1 and Table 1.

Coal of the lignite type is reported from the districts of Bandarban, Netrokona and Sunamganj, the economic feasibility and reserves of which are yet to be ascertained. Peat deposits of economic value, though not as valuable as coal, have also been found in a number of places such as Madaripur, Khulna, Moulvi-Bazar, Sunamganj and Brahmanbaria. Extraction of peat is going on from the Madaripur and Khulna peat fields. Peat occurrences are also reported from many other districts, including Dhaka city. The reserves of peat in Bangladesh are about 470 million tons (Hussain, 1995).

Hard rock: An unlimited reserve of hard rock consisting of granodiorite, quartzdiorite and gneiss of the Pre-Cambrian has been discovered at a shallow depth of $128 \mathrm{~m}$ in Maddhapara in the Dinajpur district. Pegmatite, pyrite, chalcopyrite and siderite have been observed in the vicinity of granodiorite, quartzdiorite and gneiss. Hard rock deposits are also recorded in Ranipukur and Pirganj in Rangpur district at a depth of $171 \mathrm{~m}$ and $265 \mathrm{~m}$ respectively, and from Bogra, Joypurhat-Jamalgonj, and Kansat of Rajshahi district at depths of $2,150 \mathrm{~m}, 600-667 \mathrm{~m}$ and $615 \mathrm{~m}$ respectively (Rahman, 1997).

Besides these, there are surface deposits of construction materials such as boulders, gravels etc. at Tetulia-Panchagarh in Dinajpur district; Kaptai-Alikadam-Ukhia-Teknaf-St. Martin's Island in greater Chittagong district and some other places in greater Sylhet district.

\section{Mining development of coal and hard rock}

With the assistance of Petrobangla (BOGMC- Bangladesh Oil, Gas and Mineral Corporation), an advisory organization of the UK, Wardell Armstrong carried out a feasibility study of coal in the Barapukuria coal field in Dinajpur, and confirmed 6 coal beds within the depth range of 116-506 m having an area of $5.25 \mathrm{~km}^{2}$ and reserves of 303 million tons of high-quality bituminous coal, the extraction of which is economically feasible. It was also assured that it will be possible to extract one million tons of coal per year and it will be continued up to 64 years. And on the basis of this study, Petrobangla initiated a project named 'Coal Mine Development Project' with a total estimated cost of US\$203 million, including US\$ 160 million in foreign currency, in March 1993. Later on, to implement this project a contract was signed on Feb. 1994 by Petrobangla on behalf of the Bangladesh Government and CMC (China National Machinery Import and Export Corporation) on behalf of the Chinese government at a total cost of US\$197 million, including foreign currency of US\$ 172 million from CMC.

Mining work has been going on since June 1994, and it is stated that 5 years will be required to complete the project. It is now hoped that from 1999 partial, and from 2,000-2,001, full-fledged extraction of coal will be possible on a commercial basis.

The exploitation of coal from the Khalaspir Coal Field, which is also economically feasible, is under consideration, and negotiations are being held with some foreign countries to procure funds to carry out mining work. From the Jamalgonj coal field, according to some experts, methane gas can be extracted from coal beds, but exploitation of this coal is not possible because it is too deep to be mined economically. Bangladesh is seriously considering extraction of methane gas from this field. There are more deep-seated coal fields which may be prospective for methane gas but further detailed studies are needed.

To extract hard rock in the Maddhapara area of Dinajpur district, another mining contract was signed on March 1994 by Petrobangla and the South-South Cooperation Corporation (Nam Nam) on behalf of the governments of Bangladesh and North Korea, respectively, at a total cost of US\$ 153 million, including US\$ 116 million in foreign currency provided by North Korea. At present, mining development is ongoing, and 6 years will be required to com- 
Table 2 Mining development of coal and hard rock in Bangladesh at a glance.

\begin{tabular}{|c|c|}
\hline Barapukuria Coal Mine Project & Maddhapara Hard Rock Project \\
\hline $\begin{array}{l}\text { Mining Contract Signed in March } 1994 \text { between } \\
\text { Petrobangla (Bangladesh) and CMC (China) }\end{array}$ & $\begin{array}{l}\text { Mining contract signed in March } 1994 \text { between } \\
\text { Petrobangla (Bangladesh) and Nam Nam (North Korea) }\end{array}$ \\
\hline $\begin{aligned} \text { Total Cost } & \text { US\$ } 197 \text { million } \\
& \text { US\$ } 172 \text { million in F.C. } \\
& \text { US\$ } 25 \text { million in L.C. }\end{aligned}$ & $\begin{aligned} \text { Total cost : US\$ } 153 \text { million } \\
\text { US\$ } 116 \text { million in F.C. } \\
\text { US\$ } 37 \text { million in L.C. }\end{aligned}$ \\
\hline Mining work started in 1994 & Mining work started in 1994 \\
\hline Time required to complete work is 5 Years & Time required to complete the work is 6 years \\
\hline Initial extraction will start in 1999 & Full-fledged extraction from 2000 \\
\hline Full-fledged extraction from 2000-2001 & Expected annual production is 1.65 million ton \\
\hline Expected annual production is 1.2 million tons & Market price is US\$ 47.18 million \\
\hline Market price is US\$ 90 million & Annual production cost US\$13.71 million \\
\hline Annual production cost US $\$ 40.8$ million & Foreign currency worth US\$33 million will be saved per annum \\
\hline $\begin{array}{l}\text { Foreign currency worth US\$ } 45 \text { million will be saved } \\
\text { per annum }\end{array}$ & $\begin{array}{l}\text { After a few years, the expected rate of extraction will be } 2 \text { million } \\
\text { tons per year }\end{array}$ \\
\hline $\begin{array}{l}64 \text { years will be required to extract } 300 \text { million tons of } \\
\text { coal at the above rate }\end{array}$ & Extraction will continue for $64-70$ years at the above rate \\
\hline $\begin{array}{l}\text { Several thousands of new jobs will be created both on } \\
\text { the mining site and later on in industrial sectors }\end{array}$ & $\begin{array}{l}\text { Industries will develop and thousands of new jobs will be created } \\
\text { on both mining and industrial sites }\end{array}$ \\
\hline $\begin{array}{l}10,000-15,000 \text { people will benefit through employment } \\
\text { directly or indirectly }\end{array}$ & $\begin{array}{l}10,000-15,000 \text { people will benefit through employment directly or } \\
\text { indirectly }\end{array}$ \\
\hline
\end{tabular}

(Source: Petrobangla and daily news papers)

plete the project. After three years of starting mining work i.e. from 1998, partial, and from 2000, full-fledged extraction of hard rock will be possible. The mining development of coal and hard rock is shown in Table 2.

\section{Benefit to the national economy}

The total reserves of coal of the three coal fields discovered at Barapukuria, Khalaspir and Jamalgonj, respectively is 1753 million tons.

From 2000-2001, full-fledged extraction of coal from the Barapukuria coal mine will start, and the target of extraction of coal per day is 3,300 metric tons i.e., 1.2 million tons per year. At the above rate, 64 years will be required to extract 300 million tons of coal from Barapukuria. As Barapukuria coal is of a high quality bituminous type, having a heating value of 11,040 BTU/Ib with low sulfur content, it is good for combustion to produce power. In power generation, $80 \%$ of the coal will be used for this purpose, and there is a plan to build a power plant with a $300 \mathrm{MW}$ capacity at the village of Sherpur near the Barapukuria coal field. As a result, the electrification problems of northern Bangladesh will be solved, and both industrial and agricultural sectors will benefit from electrification. The remaining $20 \%$ of the coal will be used in brick fields and for household purposes. The qualities and various uses of coal are shown in Tables 3 and 4.

At present, most of the people of Bangladesh use wood and other plant materials to generate energy, and this causes deforestation and destruction of wild life, which are great threats to the environment. All these are again responsible for the imbalance of the environmental ecosystem. Not only that, drought, created by deforestation, affects agricultural land, and continuation of this may ruin the national production. Proper utilization of coal from Barapukuria will solve the energy problems and at the same time will help to stop wide-spread deforestation and keep the environmental ecosystem balanced, thus helping to upgrade the economic condition of the country.

Table 3 Characteristics of the coal in three coal fields.

Coal field Carbon content \% Sulphur content \% Ash content \% Moisture content \% Volatile matter \% Heating value BTU/lb

\begin{tabular}{lcccccc}
\hline Barapukuria & $45.50-50.56$ & $0.42-1.33$ & $11.79-23.71$ & $2.28-3.60$ & $28.64-31.36$ & $10,547-12,757$ \\
Khalaspir & $32.09-80.81$ & $0.24-3.15$ & $7.60-50.57$ & $0.33-5.99$ & $3.73-28.86$ & $14,224-15,168$ \\
Jamalganj & 36.7 & 0.65 & 24.25 & 3.58 & 36.72 & $11,872-12,100$ \\
\hline
\end{tabular}


Table 4 Major uses of coal and hard rock of Bangladesh.

\begin{tabular}{cl}
\hline \multicolumn{1}{c}{ Coal } & \multicolumn{1}{c}{ Hard Rock } \\
\hline - Generation of power & As construction materials for \\
- Railway transportation & - Housing apartments \\
- Domestic uses as fuel & - Commercial buildings \\
$\quad$ for cooking purposes & - Roads \& Highways \\
- Various industrial uses & - Bridges, Dams, River Dykes \\
for producing heat \& & - Embankments, Flood control \\
raising steam & - Railway ballast and sleeppers \\
- Brick fields to produce & - Decoration pieces \\
heat & - Tiles, etc. \\
- Carbonization to pro- & \\
duce coke, tar, etc. & \\
\hline
\end{tabular}

At present, annual imports of hard rock are about 1.8 million tons and it is expected that 1.5-1.8 million tons of hard rock will be produced annually from the Maddhapara mine, which means 5,000-6,000 tons per day (Chowdhury, 1994). It can be said that Bangladesh will be self-sufficient in hard rock if the mine functions at full capacity. It is also hoped that sufficient granite can be mined for export. To meet the present demand, a major part of the stone used is imported from outside the country. The target of initial extraction of hard rock from the Maddhapara hard rock mine is 1.65 million tons per year. After a few years of initial extraction, it is expected to extract 2.0 million tons of stone per year. As there is a huge deposit of hard rock, it is also expected that it will be possible to extract this rock for about 64-70 years at the above rate.

These two projects will bring a remarkable change to the national economy of Bangladesh. Not only that, these projects will provide more than 30,000 new jobs opportunities both at mine sites and later on in industrial sectors which will also bring substantial benefits to the national economy.

Hard rock from Maddhapara will be used as construction materials to build housing apartments, bridges, roads, highways, dams, embankments, to control flooding and river erosion and will also be used as railway ballast, decoration pieces, tiles, etc. And the possible users of this hard rock are the authorities of Bangladesh Railways, Roads and Highways, Water Development Board, Power Development Board, and the Sea Ports, Housing and Settlement, and Local Government and Engineering departments.

\section{Conclusion}

The discovery of such huge deposits of coal and hard rock is a blessing for Bangladesh, and proper development of these resources will open a new era for the country to enter the industrial world. In the modern world, the sustainable economic conditions of any nation depend on how developed that country's industrial is, especially in the field of mineral resources. So, minerals based industries are an important factor for accelerating the economic growth of a country. Now, Bangladesh has an opportunity to build up mineral-based industries as she has sufficient mineral resources on which industries can develop. Full-capacity exploitation of these resources will create thousands of new jobs at the mine sites and later on at industrial sites, which will help to alleviate the country's poverty by providing jobs. All these together will accelerate the country's economic development. It may be concluded that proper development and utilization of these resources will help us to save a considerable amount of foreign currency and will contribute a great deal to the national economy and reshape our socio-economic infrastructure.

\section{Acknowledgements}

Thanks to the Director General of the Geological Survey of Bangladesh (GSB) for his kind permission to publish this paper. Thanks also to M.N. Hasan of GSB and M.Z. Hasan of Saga University of Japan for their kind review of the paper.

\section{References}

Akhtar, A. \& Hasan, M.N., 1994, Fossil Fuel in Bangladesh: Proc. 2nd SEGMITE Int. Conf., Karachi, pp 79-84.

Akhtar, A. \& Hasan, M.N. 1995, Mineral deposits and Mineral based industries in Bangladesh: Proc. Int. Symp. and Field Workshop on Phosphorites and other industrial mineral, Abbottabad, Pakistan (in Press).

Armstrong, W., 1991, Techno-economic feasibility study: Barapukuria Coal Project, Dinajpur, Bangladeh

Chowdhury, B.S., 1994, Mining and Quarrying sector poised to take off: The Daily Star, Dhaka, April 18, 1994.

Dainik Bangla: Contract with China for extraction of coal from Barapukuria coal field. Feb. 8, 1994

GSB, 1993, Statement of activities, Success of the Geological Survey of Bangladesh

GSB, 1994, Mineral profile of Bangladesh.

Husain, K.M. 1995, Gas and coal: 4 years development: The Dainik Dinkal, Dhaka,March, 15 .

Islam , M.N, . et. al., 1992, Geology of Khalaspir Coal Basin: Record, GSB, Vol- 6, part -5

Media Syndicate: Extraction of Hard rock, value of US\$ 40 million ton from Maddhapara hard rock mine. Dainik Bangla, July 17, 1995.

Ministry of Energy \& Mineral Resources, 1991-95: Unnyan Prabahah.

Petrobangla, 1994: Brochure-Barapukuria coal mine development project.

Petrobangla, 1994: Brochure-Maddhapara Hard Rock Mine project.

Rahman, A. 1994: Discovery of Hard Rock in Maddhapara-a prospective new frontier.The Daily Rupali, Dhaka, May 94.

Rahman, A, 1997, Mineral Resources of Bangladesh and their history: Huq Printers, Arambagh, Dhaka.

Afia Akhtar, a geologist, is working at the Geological Survey of Bangladesh as a Director. She worked on palynomorphs of Permian Gondwana coal and PlioPleistocene sediments, and also on ostracodes of Eocene and recent sediments of Bangladesh. She is interested in mineral resources, environment, and natural hazards, and also interested in popularize geosciences through geoscientific activities and geoscience education, which is a prime concern of the AGID.

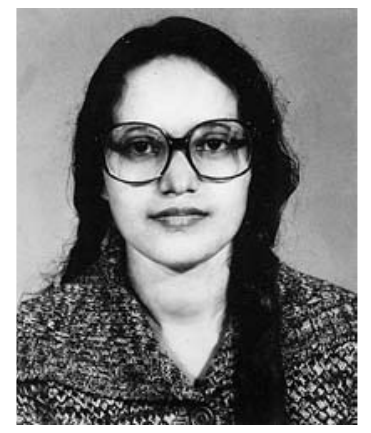

